\title{
Prilaku Generasi Milenial dalam Memilih Warung Kopi (Studi di Kota Langsa)
}

\author{
Muhammad Rizal ${ }^{\left.1^{*}\right)}$, Yudha $\mathbf{J}^{2)}$ \\ ${ }^{1 *, 2)}$ Fakultas Ekonomi, Universitas Samudra \\ e-mail: rizal_ysf@unsam.ac.id ${ }^{1 *}$
}

\begin{abstract}
Abstrak
Penelitian ini bertujuan untuk mengetahui pengaruh kelompok referensi, gaya hidup, dan harga terhadap keputusan pembelian warung kopi di Kota Langsa. Jumlah sampel dalam penelitian ini berjumlah 96 responden. Teknik pengambilan sampel yang digunakan adalah Accidental Sampling. Metode analisis data yang digunakan yaitu analisis regresi linear berganda dan pembuktian hipotesis menggunakan uji $t$, uji $F$ dan analisis koefisien determinasi. Hasil penelitian diperoleh persamaan regresi linear berganda yaitu: $Y=2.207+0.194 X_{1}+0.064 X_{2}+0.178 X_{3}$. Hasil uji $t$ menunjukkan kelompok referensi dan harga secara parsial berpengaruh signifikan terhadap keputusan pembelian, sedangkan gaya hidup tidak berpengaruh signifikan terhadap keputusan pembelian. Hasil uji F menunjukkan kelompok referensi, gaya hidup dan harga secara simultan berpengaruh signifikan terhadap keputusan pembelian. Hasil uji koefisien determinasi menunjukkan kontribusi variabel kelompok referensi, gaya hidup dan harga terhadap keputusan pembelian pada warung kopi di Kota Langsa sebesar 0.409 atau 40.9\%, sementara sisanya 0.591 atau 59.1\% dipengaruhi oleh variabel lain yang tidak diteliti dalam penelitian ini seperti lokasi, store atmosphere, kualitas pelayanan, motivasi, minat, dan lain sebagainya.
\end{abstract}

Kata kunci: Kelompok referensi, Gaya hidup, Harga dan Keputusan pembelian

\section{PENDAHULUAN}

Zaman semakin berubah, tentu saja kebutuhan dan keinginan akan sebuah produk barang dan jasa akan semakin bervariatif tergantung waktu dan intensitas kegiatan yang dilakukan. Kebanyakan masyarakat perkotaan yang setiap harinya berkutat dengan rutinitas yang padat dari pagi hingga menjelang petang pastinya membutuhkan tempat untuk melepaskan penat atau sekedar bersantai bersama teman atau keluarga sambil makan dan minum dan juga berdiskusi tentang hal-hal penting. Perilaku tersebut sering kita sebut dengan nongkrong, namun bedanya saat ini masyarakat lebih memilih tempat yang menyediakan makanan atau minuman sebagai tempat untuk mereka nongkrong. Beberapa pelaku bisnis memanfaatkan peluang ini dengan mendirikan beberapa usaha yang dapat memenuhi kebutuhan tersebut salah satunya dengan mendirikan warung kopi. Apalagi kopi sudah menjadi minuman yang sangat digemari masyarakat indonesia bahkan peminatnya terus meningkat beberapa tahun terakhir, sehingga mendirikan warung kopi merupakan ide yang sangat bagus jika ingin membuat sebuah usaha. 
Seorang konsumen biasanya mengunjungi warung kopi karena desakan kelompok referensi. Kelompok referensi merupakan individu ataupun kelompok yang dapat mempengaruhi perilaku seseorang baik secara tatap muka maupun tidak. Namun selain faktor kelompok referensi, semakin banyaknya warung kopi yang bertebaran menyebabkan terjadinya perubahan gaya hidup masyarakat yang lebih banyak bersosialisasi diluar rumah juga dapat mempengaruhi keputusan konsumen dalam memilih warung kopi.

Gaya hidup merupakan faktor perilaku konsumen yang merupakan bagian dari segmentasi psikografis. Gaya hidup adalah gambaran perilaku seseorang secara keseluruhan yang berinteraksi sesuai dengan pengaruh lingkungannya. Perubahan gaya hidup konsumen dapat dilihat dari seberapa sering konsumen tersebut mengunjungi warung kopi serta warung kopi seperti apa yang dikunjunginya. Tentunya ada faktor harga yang juga mempengaruhi konsumen dalam memilih warung kopi untuk melengkapi pengaruh gaya hidup dan kelompok referensi terhadap keputusan memilih warung kopi.

Harga merupakan sebuah nilai yang harus dikeluarkan seorang konsumen untuk memperoleh manfaat dari barang atau jasa yang diinginkannya. Harga juga mempengaruhi keputusan memilih konsumen dalam hal ini warung kopi dimana harga yang murah ataupun mahal tentunya mempengaruhi citarasa ataupun pelayanan pada warung kopi tersebut.

Kota Langsa merupakan sebuah kota yang memiliki sentra usaha warung kopi yang terbilang cukup banyak. Pada saat ini warung kopi di kota Langsa sudah mencapai puluhan tempat yang tersebar di berbagai kecamatan yang ada di Kota Langsa. Warung kopi memang menjadi tempat favorit yang di kunjungi di kota Langsa tidak terbatas waktu baik kalangan tua maupun muda, dengan puncak ramainya kunjungan warung kopi di Kota Langsa pada saat sore menjelang malam.

Peneliti melakukan observasi ke beberapa warung kopi di Kota Langsa yang ramai dikunjungi oleh konsumen khususnya kelompok millenial. Konsumen yang mengunjungi warung kopi biasanya datang bersama orang-orang yang kemungkinan menjadi referensi mereka dalam memilih warung kopi. Kelompok referensi membawa pengaruh informasi kepada konsumen sehingga konsumen dapat mempercayai saran dari mereka karena pengetahuan dan informasi yang lebih baik. Kelompok referensi tersebut merupakan kelompok referensi yang sangat dekat dengan konsumen.

Kemudian aktivitas masyarakat yang lebih aktif di luar rumah membawa pengaruh gaya hidup hedonis pada masyarakat Kota Langsa. Gaya hidup hedonis merupakan gaya hidup yang mengutamakan kesenangan konsumen sehingga konsumen memilih, menggunakan atau membeli produk yang dapat menggambarkan dirinya dengan kesenangannya.

Dari faktor harga yang di tetapkan oleh warung kopi masih menjadi faktor pertimbangan karena konsumen warung kopi tersebut rata-rata masih berstatus pelajar ataupun mahasiswa. Bagi konsumen kalangan dewasa yang berpenghasilan cukup dan lebih dari cukup mungkin tidak mempermasalahkan 
besarnya harga yang mereka bayar untuk menikmati manfaat dari warung kopi jika harga yang ditawarkan tersebut disertai dengan kualitas layanan yang diberikan oleh warung kopi sehingga menjadi nilai tersendiri bagi konsumen untuk kembali mengunjungi warung kopi.

Berdasarkan latar belakang di atas, yang menjadi tujuan dalam penelitian ini adalah:

1. Untuk mengetahui pengaruh kelompok referensi terhadap keputusan pembelian pada warung kopi di Kota Langsa?

2. Untuk mengetahui pengaruh gaya hidup terhadap keputusan pembelian pada warung kopi di Kota Langsa?

3. Untuk mengetahui pengaruh harga terhadap keputusan pembelian pada warung kopi di Kota Langsa?

4. Untuk mengetahui pengaruh kelompok referensi, gaya hidup dan harga terhadap keputusan pembelian pada warung kopi di Kota Langsa?

\section{TINJAUAN PUSTAKA}

\section{Perilaku Konsumen}

Menurut Setiadi (2010), perilaku konsumen adalah tindakan yang langsung terlibat dalam mendapatkan, mengonsumsi, dan menghabiskan produk atau jasa, termasuk proses keputusan yang mendahului dan menyusuli tindakan ini. Perilaku konsumen adalah perilaku yang ditampilkan oleh konsumen saat mereka mencari, membeli, menggunakan, mengevaluasi dan menghabiskan produk dalam rangka memenuhi kebutuhan dan keinginannya. Perilaku tersebut dapat ditampilkan oleh konsumen akhir (konsumen rumah tangga maupun konsumen perantara) (Priansa, 2017).

\section{Kelompok Referensi}

Sumarwan (2011) menyatakan bahwa kelompok referensi (reference group) adalah seorang individu atau sekelompok orang yang secara nyata mempengaruhi perilaku seseorang. Kelompok referensi adalah seseorang atau kelompok orang yang dijadikan acuan oleh seseorang dalam membentuk pandangan tentang nilai tertentu, sikap atau pedoman berperilaku yang memiliki ciri-ciri khsusus (Nitisusastro, 2013).

Engel dalam Wibowo dan Riyadi (2017) menyatakan indikator kelompok referensi sebagai berikut:

1. Pengetahuan kelompok referensi mengenai produk: Kelompok referensi mempengaruhi konsumen dengan pengetahuannya tentang sebuah produk dan menceritakan spesifikasi produk tersebut.

2. Kredibilitas dari kelompok referensi: Konsumen memiliki keyakinan yang tinggi terhadap apa yang disampaikan kelompok referensi sehingga mampu menerima apa yang di ceritakan kelompok referensi. 
3. Pengalaman dari kelompok referensi: Kelompok referensi juga menceritakan pengalaman dalam menggunakan sebuah produk barang atau jasa untuk semakin meyakinkan konsumen.

4. Keaktifan kelompok referensi: Dalam beberapa waktu, kelompok referensi sangat intens mengajak konsumen dalam keterlibatannya memilih sebuah produk barang atau jasa.

5. Daya tarik kelompok referensi: Kelompok referensi menyampaikan ketertarikan sebuah produk barang atau jasa yang sangat sesuai dengan konsumen yang dipengaruhinya.

\section{Gaya Hidup}

Menutur Kotler dan Keller (2009), gaya hidup adalah pola hidup seseorang di dunia yang tercermin dalam kegiatan, minat, dan pendapat. Sedangkan menurut Sugihartati (2010), Gaya hidup merupakan suatu adaptasi aktif individu terhadap kondisi sosial dalam rangka memenuhi kebutuhan untuk menyatu dan bersosialisasi dengan orang lain.

Priansa (2017) menyatakan bahwa Indikato-indikator dalam mengukur gaya hidup adalah:

1. Kegiatan (Activities): Menyatakan apa yang dikerjakan konsumen, produk apa yang dibeli atau di gunakan, kegiatan apa yang mereka lakukan untuk mengisis waktu luang, serta berbagai aktivitas lainnya.

2. Minat (Interest): Minat berhubungan dengan kesukaan, kegemaran dan prioritas dalam hidup konsumen.

3. Pendapat (Opinion): Pendapat merupakan pandangan dan perasaan konsumen dalam menanggapi isuisu tertentu.

\section{Harga}

Menurut Subagyo (2010), harga adalah jumlah pelanggan membayar untuk produk. Sedangkan menurut Alma (2014), harga adalah nilai suatu barang yang dinyatakan dengan uang.

Pangestu dan Suryoko (2016) mengemukakan indikator harga yaitu:

1. Keterjangkauan harga yang dimiliki: Sebuah produk yang harganya murah akan lebih diminati oleh konsumen jika segala aspek yang diinginkan konsumen sudah tercapai pada produk tersebut..

2. Kesesuaian harga dengan kualitas produk: Konsumen menilai harga produk dengan kualitas produk yang ditawarkan, apakah harga yang ditawarkan diiringi dengan baiknya kualitas produk atau tidak..

3. Harga produk dibandingkan dengan harga pesaing: Persaingan harga produk sejenis juga akan diperhatikan oleh konsumen dalam menilai sebuah produk. 


\section{Keputusan Pembelian}

Menurut Swastha dan Handoko (2008), Keputusan pembelian merupakan proses dalam pembelian yang nyata, apakah membeli atau tidak. Sedangkan Suharno dan Sutarso (2010) menyatakan bahwa keputusan pembelian adalah perilaku yang ditunjukkan oleh konsumen dalam membeli produk, yaitu dari mulai munculnya kebutuhan, mencari informasi, mengevaluasi, memutuskan membeli dan perilaku setelah pembelian.

Kotler dan Amstrong (2008), indikator untuk mengukur keputusan pembelian sebagai berikut:

1. Keinginan untuk menggunakan produk: Konsumen yang ingin menggunakan produk biasanya akan mencari informasi mengenai produk yang akan dibelinya untuk mengetahui keunggulan-keunggulan yang ada pada produk tersebut.

2. Keinginan untuk membeli produk: Setelah konsumen mengetahui keunggulan suatu produk maka ia mempunyai keinginan untu membelinya.

3. Memberikan rekomendasi kepada orang lain: Konsumen yang telah menggunakan suatu produk biasanya akan merekomendasikan orang lain untuk menggunakan produk yang pernah dikonsumsinya.

4. Melakukan pembelian ulang: Jika konsumen merasa puas dengan produk yang dibelinya maka ia akan membeli kembali produk tersebut.

\section{Kerangka Pemikiran}

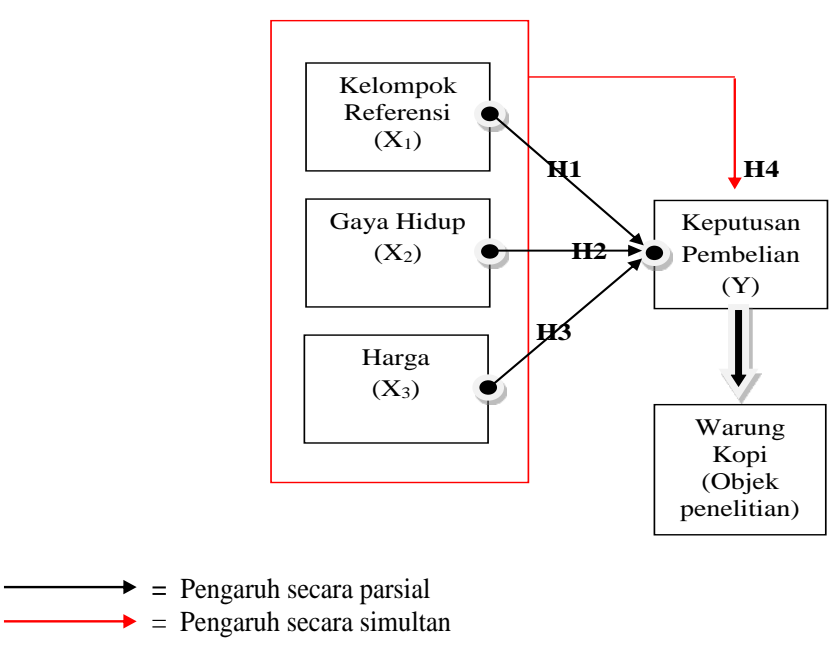

Gambar 1. Kerangka Pemikiran

\section{Hipotesis}

H1. Diduga kelompok referensi berpengaruh signifikan terhadap keputusan pembelian pada warung kopi di Kota Langsa. 
H2. Diduga gaya hidup berpengaruh signifikan terhadap keputusan pembelian pada warung kopi di Kota Langsa.

H3. Diduga harga berpengaruh signifikan terhadap keputusan pembelian pada warung kopi di Kota Langsa.

H4. Diduga kelompok referensi, gaya hidup, dan harga berpengaruh signifikan terhadap keputusan pembelian pada warung kopi di Kota Langsa.

\section{METODE PENELITIAN}

\section{Populasi dan Sampel}

Populasi adalah wilayah generalisasi yang terdiri dari objek atau subjek yang mempunyai kualitas dan karakteristik tertentu yang dipelajari oleh peneliti untuk ditarik kesimpulannya (Sugiyono, 2012). Populasi pada penelitian ini adalah konsumen yang mengunjungi warung kopi yang ada di Kota Langsa. Sampel adalah bagian dari jumlah dan karakteristik yang dimiliki oleh populasi tersebut (Sugiyono, 2012). Penelitian ini akan menggunakan metode Non probability sampling dengan memakai accidental sampling yang merupakan teknik penentuan sampel berdasarkan kebetulan, yaitu siapa saja yang secara kebetulan/Insidental bertemu dengan peneliti dapat digunakan sebagai sampel, bila dipandang orang yang kebetulan ditemui cocok sebagai sumber data (Sugiyono, 2012). Karena besarnya populasi dalam penelitian tidak diketahui secara pasti, maka pengambilan sampel penelitian menggunakan rumus unknown population berikut ini (Sarwono, 2013):

$\mathrm{n}_{0}=\mathrm{Z}^{2} \mathrm{pq}$

$\mathrm{e}^{2}$

Dimana:

$\mathrm{n}_{0}=$ Besarnya sampel

$\mathrm{Z}^{2}=$ Absisca kurva normal yang memotong area sisi (tails), atau 1 tingkat kepercayaan, sebesar 95\% atau 1,96

$\mathrm{e} \quad=$ Tingkat kepercayaan yang diinginkan $10 \%$

$\mathrm{p}=$ Proporsi yang diestimasi suatu atribut yang dalam populasi yaitu 0,5

$\mathrm{q}=1-\mathrm{p}$

$\mathrm{n}_{0}=(1,96)^{2}(0,5)(0,5)$

$(0,1)^{2}$

$\mathrm{n}_{0}=96,04$ 
Dari hasil perhitungan sampel maka jumlah sampel dalam penelitian ini adalah 96,04 atau dibulatkan menjadi 96 responden.

\section{Metode Pengumpulan Data}

Penelitian ini menggunakan metode pengumpulan data dengan melakukan penelitian lapangan dan penelitian kepustakaan (literature review). Penelitian lapangan dimulai dengan melakukan observasi ke objek penelitian yaitu warung kopi yang ada di Kota Langsa kemudian melakukan penyebaran kuesioner kepada konsumen warung kopi dan melakukan dokumentasi penelitian sebagai bukti telah melakukan proses penelitian. Setiap pernyataan kuesioner diberikan skor dengan menggunakan skala likert dengan skala skor 1-5. Penelitian lapangan dilakukan untuk mencari literatur atau kajian secara studi terhadap penelitian seperti menuangkan teori-teori yang berkaitan dengan variabel penelitian yang berasal dari buku-buku, sumber jurnal, internet atau artikel yang sesuai.

\section{Uji Validitas dan Uji Reliabilitas}

Validitas adalah suatu ukuran yang menunjukkan tingkat-tingkat kevalidan atau kesahihan suatu instrumen. Suatu instrumen yang valid atau sahih mempunyai validitas yang tinggi. Sebaliknya, instrumen yang kurang valid berarti memiliki validitas rendah (Arikunto, 2013:211). Untuk mengetahui item pertanyaan mana yang tidak memiliki validitas yang memadai maka batas minimum $r$ ialah 0,30 . Bila dalam kuesioner ada item pertanyaan yang mendapat koefisisen korelasi $<0,30$ maka pertanyaan tersebut diperbaiki atau tidak jarang pula item pertanyaan tersebut didrop dari kuesioner (Sinulingga, 2013).

Reliabilitas menunjuk pada satu pengertian bahwa suatu instrumen cukup dapat dipercaya untuk digunakan sebagai alat pengukur data karena instrumen tersebut sudah baik (Arikunto, 2013). Pernyataan kuesioner yang telah valid dalam uji validitas kemudian diuji keandalannya dengan menggunakan uji reliabilitas. Suatu konstruk atau variabel dapat dikatakan reliabel jika memberikan nilai cronbach alpha > 0,60 (Ghozali, 2008).

\section{Uji Normalitas}

Uji normalitas bertujuan untuk mengetahui apakah variabel dependen, independen atau keduanya berdistribusi normal, mendekati normal atau tidak. Model regresi yang baik hendaknya berdistribusi normal atau mendekati normal. Cara mengetahuinya dengan menggunakan gambaran data melalui sebuah grafik atau dengan menggunakan uji Kolmogorov-Smirnov (Umar, 2009). Jika dilihat dengan menggunakan grafik, data berdistribusi normal dicirikan dengan data yang mengikuti garis diagonal grafik. Sedangkan jika dilihat dengan menggunakan uji Kolmogorov-Smirnov, maka kriterianya sebagai 
berikut: Jika nilai Asymp. Sig (2-tailed) > sig. $\alpha(10 \%)$ maka distribusi data normal; Jika nilai Asymp. Sig (2-tailed) $<$ sig. $\alpha(10 \%)$ maka distribusi data tidak normal.

\section{Uji Heteroskedasitas}

Uji heteroskedasitas dilakukan untuk mengetahui apakah dalam sebuah model regresi terjadi ketidaksamaan varians dari suatu residual suatu pengamatan ke pengamatan yang lain. Jika varians suatu pengamatan ke pengamatan yang lain tetap, disebut homoskedasitas. Sementara itu, untuk varians yang berbeda disebut heteroskedasitas. Model regresi yang baik adalah yang tidak terjadi heteroskedasitas (Umar, 2009). Gejala tersebut dapat dilihat dengan menggunakan grafik Scatterplot. Jika grafik menunjukkan pola-pola tertentu, maka telah terjadi heteroskedasitas, dan jika tidak menunjukkan pola tertentu dan menyebar maka tidak terjadi heteroskedasitas.

\section{Uji Multikolinearitas}

Uji multikolinearitas dilakukan untuk mengetahui apakah pada model regresi ditemukan adanya korelasi antar variabel independen. Jika terjadi korelasi, terdapat masalah multikolinearitas yang harus diatasi (Umar, 2009:177). Kriteria untuk uji multikolinearitas yaitu: Jika nilai Variance Inflation Factor (VIF) pada tabel statistik < 10 atau nilai Tolerance > 0,1, maka model regresi bebas dari multikolinearitas; Jika nilai Variance Inflation Factor (VIF) pada tabel statistik $>10$ atau nilai Tolerance $<0,1$, maka model regresi terdapat masalah multikolinearitas yang harus diatasi.

\section{Analisis Regresi Linear Berganda}

Analisis regresi berganda digunakan untuk menganalisis pengaruh kelompok referensi, gaya hidup, dan harga terhadap keputusan pembelian pada warung kopi dikota Langsa. Persamaan tersebut dikemukakan oleh Sugiyono (2012:277) dan disesuaikan dengan formulasi sebagai berikut:

$$
\mathrm{Y}=\mathrm{a}+\mathrm{b}_{1} \mathrm{X}_{1}+\mathrm{b}_{2} \mathrm{X}_{2}+\mathrm{b}_{3} \mathrm{X}_{3}+\mathrm{e}
$$

\section{Uji t (Uji Parsial)}

Pengujian secara parsial digunakan untuk membuktikan apakah terdapat pengaruh antara kelompok referensi $\left(\mathrm{X}_{1}\right)$, gaya hidup $\left(\mathrm{X}_{2}\right)$, dan harga $\left(\mathrm{X}_{3}\right)$ terhadap Keputusan pembelian $(\mathrm{Y})$. Jika nilai $\mathrm{t}_{\text {sig. }}<0.10$, maka variabel independen (kelompok referensi, gaya hidup dan harga) secara parsial berpengaruh signifikan terhadap variabel dependen (keputusan pembelian). 


\section{Uji F (Uji Simultan)}

Pengujian simultan (uji F) digunakan untuk menguji secara bersama-sama apakah terdapat pengaruh antara kelompok referensi $\left(\mathrm{X}_{1}\right)$, gaya hidup $\left(\mathrm{X}_{2}\right)$ dan harga $\left(\mathrm{X}_{3}\right)$ terhadap keputusan pembelian (Y). Jika nilai $\mathrm{F}_{\text {sig. }}<0.10$, maka variabel independen (kelompok referensi, gaya hidup,

dan harga) secara simultan berpengaruh signifikan terhadapa variabel dependen (keputusan pembelian).

\section{Koefisien Determinasi $\left(\mathbf{R}^{2}\right)$}

Koefisien determinasi $\left(\mathrm{R}^{2}\right)$ merupakan besarnya kontribusi variabel bebas terhadap variabel tergantungnya (Suliyanto, 2011). Untuk jumlah variabel independen lebih dari dua, lebih baik menggunakan Adjusted $R$ Square (selalu lebih kecil dari $R$ Square) untuk menjelaskan variasi variabel independen (kelompok referensi, gaya hidup dan harga) terhadap variabel dependen (keputusan pembelian).

\section{HASIL DAN PEMBAHASAN}

\section{Identifikasi Karakteristik Responden}

Responden dalam penelitian ini merupakan konsumen yang mengunjungi warung kopi di Kota Langsa dengan ketentuan sampel yang ditetapkan sebesar 96 responden. Karakteristik responden berdasarkan jenis kelamin didominasi oleh laki-laki sebanyak 77 responden (80.2\%). Karakteristik responden berdasarkan umur didominasi oleh kelompok umur 17-23 tahun sebanyak 44 responden (45.8\%). Karakteristik responden berdasarkan pendidikan didominasi oleh pendidikan sarjana sebanyak 41 responden (42.7\%). Karakteristik responden berdasarkan profesi didominasi oleh mahasiswa / pelajar sebanyak 31 responden (32.3\%). Dan karakteristik responden berdasarkan frekuensi berkunjung ke warung kopi didominasi oleh frekuensi berkunjung > 4 kali sebanyak 52 responden $(54.2 \%)$.

\section{Pembahasan}

\section{Analisis Regresi Linear Berganda}

Hasil analisis statistik dapat dilihat pada tabel 1 berikut:

Tabel 1. Hasil Analisis Statistik

\begin{tabular}{lcccc}
\hline \multicolumn{1}{c}{ Variabel } & B & t & Sig t \\
\hline & & & & \\
Konstanta & 2,207 & 5,099 & 0,000 \\
Kelompok Referensi & 0,194 & 2,370 & 0,020 \\
Gaya Hidup & 0,064 & 0,824 & 0,412 & \\
Harga & 0,178 & 1,997 & 0,049 \\
\hline & & & \\
F & 4,889 & & \\
Sig. F & 0,003 & &
\end{tabular}


Dari hasil tersebut dapat ditulis persamaan regresi sebagai berikut:

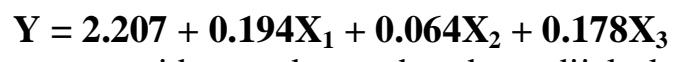

Persamaan regresi berganda tersebut dapat dijelaskan sebagai berikut:

1. Konstanta sebesar 2.207 menunjukkan nilai keputusan pembelian apabila kelompok referensi, gaya hidup dan harga bernilai tetap.

2. Variabel kelompok referensi $\left(\mathrm{X}_{1}\right)$ menunjukkan pengaruh yang positif terhadap keputusan pembelian.

Dengan kata lain, apabila kelompok referensi mengalami peningkatan sebesar satu satuan maka keputusan pembelian akan bertambah sebesar 0.194 dengan asumsi variable gaya hidup dan harga bernilai tetap.

3. Variabel gaya hidup $\left(\mathrm{X}_{2}\right)$ menunjukkan pengaruh yang positif terhadap keputusan pembelian. Dengan kata lain, apabila gaya hidup mengalami peningkatan sebesar satu satuan maka keputusan pembelian akan bertambah sebesar 0.064 dengan asumsi variable kelompok referensi dan harga bernilai tetap.

4. Variabel harga $\left(\mathrm{X}_{3}\right)$ menunjukkan pengaruh yang positif terhadap keputusan pembelian. Dengan kata lain, apabila gaya hidup mengalami peningkatan sebesar satu satuan maka keputusan pembelian akan bertambah sebesar 0.178 dengan asumsi variable kelompok referensi dan gaya hidup bernilai tetap.

\section{Uji t (Uji Parsial)}

Uji t yaitu suatu uji untuk mengetahui signifikansi pengaruh variabel bebas (kelompok referensi, gaya hidup dan harga) secara parsial ataupun individu menerangkan variabel terikat (keputusan pembelian). Hasil uji t dapat dilihat pada Tabel 4 dengan sig $\alpha 0.10$ (10\%). Dari tabel tersebut dapat dijelaskan bahwa:

1. Hasil uji $t$ diketahui nilai $t_{\text {sig. }}$ sebesar $0.020<0.10$ maka Ha diterima, yang berarti bahwa kelompok referensi berpengaruh signifikan terhadap keputusan pembelian pada warung kopi di Kota Langsa sehingga hipotesis 1 (H1) dalam penelitian ini dapat diterima.

2. Hasil hasil uji t diketahui nilai $t_{\text {sig. }}$ sebesar $0.412>0.10$ maka Ha ditolak, yang berarti bahwa gaya hidup tidak berpengaruh signifikan terhadap keputusan pembelian pada warung kopi di Kota Langsa sehingga hipotesis 2 (H2) dalam penelitian ini tidak terbukti kebenarannya. Hal tersebut dikarenakan konsumen tidak memandang kebiasaan mereka mengunjungi warung kopi untuk nongkrong sebagai gaya hidup, melainkan sebuah minat yang dipengaruhi oleh budaya yang telah mengakar pada masyarakat sekitarnya dan motivasi yang lebih mendorong ke tindakan sosial.

3. Hasil uji $t$ diketahui nilai $t_{\text {sig. }}$ sebesar $0.049<0.10$ maka Ha diterima, yang berarti bahwa harga berpengaruh signifikan terhadap keputusan pembelian pada warung kopi di Kota Langsa sehingga hipotesis 3 (H3) dalam penelitian ini dapat diterima. 


\section{Uji F (Uji Simultan)}

Uji F yaitu uji untuk mengetahui signifikansi pengaruh variabel bebas (kelompok referensi, gaya hidup dan harga) secara simultan ataupun bersama-sama menerangkan variabel terikat (keputusan pembelian).

Dari Tabel 4 tersebut dapat diketahui nilai $\mathrm{F}_{\text {sig. }}$ sebesar 0,003 . Oleh karena nilai $\mathrm{F}_{\text {sig. }}<$ sig. $\alpha(0.003$ < 0.10), maka Ha diterima. Artinya kelompok referensi, gaya hidup dan harga secara simultan berpengaruh signifikan terhadap keputusan pembelian. Dengan demikian maka hipotesis 4 (H4) dalam penelitian ini diterima.

\section{KESIMPULAN DAN SARAN}

\section{Kesimpulan}

Setelah dilakukan pengujian, hasil penelitian dan pembahasan maka dapat disimpulkan yaitu:

1. Hasil persamaan regresi linier berganda menunjukkan $Y=2.207+0.194 X_{1}+0.064 X_{2}+0.178 X_{3}$. Konstanta sebesar 2.207 menunjukkan nilai keputusan pembelian apabila kelompok referensi, gaya hidup dan harga bernilai tetap. Koefisien variabel kelompok referensi, gaya hidup dan harga menunjukkan bahwa variabel kelompok referensi, gaya hidup dan harga dapat meningkatkan keputusan pembelian pada warung kopi di Kota Langsa.

2. Hasil uji t diketahui bahwa kelompok referensi berpengaruh signifikan terhadap keputusan pembelian pada warung kopi di Kota Langsa, gaya hidup tidak berpengaruh signifikan terhadap keputusan pembelian pada warung kopi di Kota Langsa dan harga berpengaruh signifikan terhadap keputusan pembelian pada warung kopi di Kota Langsa.

3. Hasil Uji F diketahui bahwa kelompok referensi, gaya hidup dan harga secara simultan berpengaruh signifikan terhadap keputusan pembelian pada warung kopi di Kota Langsa.

\section{REFERENSI}

Alma, Buchari. 2014. Manajemen Pemasaran Dan Pemasaran Jasa. Bandung: Alfabeta.

Arikunto, Suharsmi. 2013. Prosedur Penelitian Suatu Pendekatan Praktik. Jakarta: Rineka Cipta. Ghozali, Imam. 2008. Aplikasi Multivariat Dengan Program SPSS. Edisi Kedua. Semarang: UNDIP. Kotler, Philip dan Garry Armstrong. 2008. Prinsip-Prinsip Pemasaran. Jilid 1. Edisi 12. Jakarta: Erlangga.

dan Kevin Lane Keller. 2009. Manajemen Pemasaran. Jilid I. Edisi 13. Jakarta: Erlangga.

Nitisusastro, Mulyadi. 2013. Perilaku Konsumen Dalam Perspektif Kewirausahaan. Bandung: Alfabeta.

Pangestu dan Suryoko. 2016. Pengaruh Gaya Hidup dan Harga Terhadap Keputusan Pembelian (Studi Kasus Pada Pelanggan Peacockoffie Semarang. Jurnal Administrasi Bisnis. Vol. 5 No. 1: Hal 6370.

Priansa, Donni Juni. 2017. Perilaku Konsumen dalam Persaingan Bisnis Kontemporer. Bandung : Alfabeta.

Sarwono, Jonathan. 2013. Strategi Melakukan Riset. Yogyakarta: Andi. 
Setiadi, Nugroho J. 2010. Perilaku Konsumen. Cetakan 4, Edisi Revisi. Jakarta: Kencana.

Sinulingga, Sukaria. 2013. Metode Penelitian. Medan: USU Press

Subagyo, Ahmad. 2010. Marketing In Business. Jakarta: Mitra Wacana Media.

Sugihartati, Rahma. 2010. Membaca Gaya Hidup dan Kapitalisme. Yogyakarta: Graha Ilmu.

Sugiyono. 2012. Metode Penelitian Bisnis. Bandung: Alfabeta.

Suharno dan Sutarso. 2010. Marketing In Practice. Cetakan Pertama, Edisi Pertama. Yogyakarta: Graha Ilmu.

Suliyanto. 2011. Ekonometrika Terapan - Teori dan Aplikasi dengan SPSS. Yogyakarta: CV. Andi Offset.

Sumarwan, Ujang. 2011. Perilaku Konsumen: Teori dan Penerapan dalam Pemasaran. Bogor: Ghalia Indonesia.

Swastha, Basu dan Hani Handoko. 2008. Manajemen Pemasaran, Analisa Perilaku Konsumen. Cetakan 4, Edisi Pertama. Yogyakarta: BPFE.

Umar, Husein. 2009. Metode Penelitian Untuk Skripsi dan Tesis Bisnis. Edisi Kedua. Jakarta: Rajawali Pers.

Wibowo dan Riyadi. 2017. Pengaruh Gaya Hidup, Prestise dan Kelompok Referensi Terhadap Keputusan Pembelian (Studi Pada Konsumen Taiwan Tea House Semarang). Prosiding Seminar Nasional Riset Manajemen \& Bisnis. Hal: 97-113. 